\title{
na mesma cela, 99 homens e 3 mulheres
}

\section{Fabiana Moraes}

\section{\#estupro \#sistemaprisional \#HIV \#mulheresnegras \#mulherestrans}

Foi a terceira vez que Fernanda rodou. Acusaram: tinha trinta e seis pedras de crack. Ela diz: não tinha. Foram plantadas. Nunca traficou. Extorquiu, e por isso foi presa duas vezes. Tráfico, não. Encaminharam para o Cotel e depois para o Frei Damião de Bozzano.

(Complexo Prisional do Curado)

Estava com Tainá e Michele, mulheres trans como ela.

Colocaram todas na triagem, cela três, a mais lotada.

Noventa e nove homens lá dentro. Essa primeira noite, nessa terceira queda, nesse presídio, está rasgada e cicatrizada nas coxas de Fernanda. No peito, no pescoço, intestinos, artérias. Tinha 19 anos, agora 25, quando Playboy, no meio dos outros presos, apontou para ela e disse: tu vai ser só minha. Exercia o poder e os privilégios de quem estava há mais tempo ali dentro. Era também mesário de outro pavilhão, o Galpão (atual pavilhão 4). Foi ele quem talhou o corpo da jovem quando a resistência aconteceu. 
Pediu para os colegas de cela segurarem ela, disse que ela tinha que dar para ele, que era tudo puta.

Ela se esquivava, ele pegou o pontiagudo chuço, arma por excelência das prisões do Estado. Essa havia sido extraída de um ventilador. Desferiu três golpes nas pernas de Fernanda. Depois, a estuprou. Fernanda sentiu quando Playboy ejaculou.

O que era gozo para ele era abismo para ela.

No banheiro, outros homens gozavam em Tainá e Michele. Ambas não ofereceram resistência - temiam sofrer o que Fernanda passou.

Chuço e corpo rasgado. Aí os detentos se revezavam. Fizeram fila.

No outro dia, uma delas foi para a enfermaria, quase desfalecida. O ânus sangrava. Na cela, Fernanda decidiu: deitaria com Playboy em troca de uma exclusividade que poderia garantir alguma segurança. Para ele, não voltaria a dizer não. Temia sofrer o que as colegas passaram. Temia terminar na enfermaria.

Ou pior.

Os 99 homens mantinham as três mulheres nos fundos da cela, uma garantia de que elas não falariam sobre o que acontecia ali para algum agente quando um deles passasse perto das grades. Mas não, é claro, que eles não soubessem. Um dia um agente chamado Marlon entrou no micro-inferno institucional, 102 pessoas o habitando, para escolher quem participaria de uma partida de futebol.

Fernanda aproveitou o momento, chegou perto e, disfarçando, contou. Ali fizeram um trato: ela cuidaria das roupas, dos sapatos,

da faxina de alguns agentes. "Serviço de mulher".

Ele a manteria trabalhando e assim longe, durante o dia, dos 99 homens.

Mas à noite, ela voltava.

E Playboy vinha exercer seus privilégios.

Sem grito de Fernanda, sem resistência de Fernanda, parecia consensual. 
Assim, Fernanda continuava conversando com o abismo. Nesse momento, o ano era 2010, fazia quatro anos que ela saíra de casa.

Tinha 15 anos e coragem de contar para a mãe que havia ficado com um rapaz.

Achou que a reação dela não seria ruim: se davam bem.

Mas a convivência tornou-se seca. Saiu de lá. Foi viver nas ruas do centro.

Foi quando aprendeu que poderia ganhar dinheiro apenas com a promessa de sexo. Entrava nos carros dirigidos por homens que não se importavam em explorar menores sexualmente. Quando eles estavam prestes a começar, ela anunciava a idade. Outras meninas acompanhavam a ação, fora do carro.

Assustados, eles pagavam o valor do programa, às vezes mais.

A manobra era acompanhada pela polícia. $O$ trato: davam $\mathrm{R} \$ 50$ dia sim, dia não, aos PMs responsáveis pela área. Aí acontecia todo um mise-en-scène: às vezes eles colocavam no carro, davam uns tapas e liberavam as meninas mais à frente (perto da Rua do Riachuelo). Com o tempo, as abordagens foram ficando mais violentas. Fernanda lembra que doía especialmente quando uma policial feminina era chamada. "Ela só chegava na hora da porrada. Porque quando ela batia não ficava marca." Na última vez, veio com uma faca e cortou o cabelo da jovem que decidiu: não iria mais pagar os $\mathrm{R} \$ 50$ para a polícia. Passou a orientar as outras meninas a fazer o mesmo. No dia que foi presa pela terceira vez, saía à noite do terreno abandonado que havia perto do antigo colégio Carneiro Leão.

Aí deu de cara com a viatura.

Os policiais quiseram saber porque ela espalhara entre as outras garotas a supressão do pagamento. Estava atrapalhando os ganhos deles.

Os $\mathrm{R} \$ 50$ em troca da oportunidade de continuarem pelas ruas. Um tempo depois, veio a viatura. Foi presa, sem saber exatamente porque. Quando chegou ao Cotel, chamaram para assinar o atestado de culpa e aí ela entendeu que,

segundo os policiais (os mesmos que a prenderam nas duas vezes anteriores) 
ela foi detida por tráfico.

Foi depois de lá que foi para o Frei Damião.

E foi aí que apareceu Playboy. "Pode estuprar. É tudo puta."

Foram quase dois meses na triagem. Ao contrário dela, que tinha um "padrinho", as meninas passaram por outras celas, nas quais havia igualmente enorme abuso sexual ("isso era o tempo todo"). Na verdade, piorava: como vinham de outro ambiente, de outra cela, e não conheciam ninguém, não conseguiam canto para deitar e dormir. Quando voltavam para os 99, quando podia, Fernanda levava uma marmita com muita comida e dividia com as duas. Trabalhar para os agentes foi garantia de uma gota de poder a mais. Aí souberam que ela tin

a curso superior de enfermagem e a encaminharam para "Dra. $L u^{\prime}$. Como o fato de ter sido e continuar sendo estuprada não era problema para os agentes que conheciam a condição das três mulheres, ela decidiu voltar a falar do assunto para a profissional. Apontou para Playboy e contou o que acontecera dias antes. "Ele tem HIV, Fernanda", disse a médica.

Naquela primeira noite, naquela terceira queda, naquele presídio, ela sabia, quando Playboy ejaculou, que não seria a mesma coisa.

corpo confirmou.

Entrou em depressão, teve crises de pânico, parou de comer. $\bigcirc$ peso despencou.

Vomitava muito.

A imunidade baixou, as manchas começaram a aparecer.

Diarreia. Pele seca. Fernanda não era Fernanda.

Até hoje se ressente de ter acreditado que Dra. Lu cuidaria dela, ao contrário dos agentes. "Não tomei nada, não tive tratamento. Se tivessem me submetido a uma profilaxia pós-exposição, tinha menos chance de ter sido contaminada. Ali, acabou para mim."

É difícil dizer: recomenda-se que as drogas passem a ser usadas no máximo após 72 horas da provável contaminação. 
Fernanda não sabe se Tainá e Michele foram contaminadas.

"Playboy se transformou do ruim pro bom. Porque no final foi melhor pra mim. Pelo meno sei de quem me contaminei." Depois que soube do resultado, foi transferida para o Aníbal Bruno, também no Complexo Prisional. São sete mil pessoas reunidas em um espaço destinado a 1.819 presos. Fernanda sobreviveu um ano e onze meses por lá. Saiu e voltou,

fragilizada, a morar com a mãe, cuja companhia havia deixado aos 15 anos.

Não cabia filho gay ali.

Muito menos quando esse filho gay era, na verdade, uma mulher transexual. O pânico não passou: Fernanda não conseguia ir a lugares mais movimentados, tampouco fechados. Ainda tem problemas com isso. "Não gosto. Parece que todo mundo sabe o que tenho." Começou um tratamento psicológico gratuito e duas drogas foram recomendadas: fluoxetina e clonazepan

("se não tomar, sinto o corpo formingando").

A relação amorosa foi mantida. Mas com sofrimento.

Fernanda se preocupa com o companheiro, tem medo de contaminá-lo. No meio disso tudo, continuou se cuidando.

A terapeuta pedia para ela, aos poucos, ir saindo de casa.

Até o portão, ao menos. Que ficasse ali, depois entrasse. Que quando se sentisse segura, saísse.

Demorou um pouco, mas conseguiu.

O tempo nas ruas trouxe outro ganho além daquele que ensina a dar conta da sobrevivência. Aproximou-se de outras mulheres trans.

Conheceu grupos que acenavam alguma ajuda nos momentos críticos.

Quando estava pronta, foi trabalhar no Grupo de Trabalhos Posithivo, O GTP+, voltado para pessoas que convivem com HIV ou aids e profissionais do sexo. 
Meses depois, foi convidada pelo ex-governador Eduardo Campos para integrar o núcleo LGBT da Secretaria de Desenvolvimento Social, Criança e Juventude. Integra hoje a Secretaria Executiva de Segmentos Sociais, voltada para o público LGBT, idosos e pessoas com deficiência, além de questões relacionadas à igualdade racial.

Hoje, Fernanda Falcão é uma presença importante e simbólica dentro do governo do Estado.

0 mesmo governo que ela não quis processar porque teve medo de sofrer retaliação.

0 mesmo governo que não a protegeu quando ela foi encarcerada.

0 mesmo governo que permitiu sua contaminação.

0 mesmo governo que a convidou para uma campanha institucional

e depois a limou das fotografias de divulgação.

0 mesmo governo que hoje precisa pagar sua enorme dívida com ela.

Foto: Ricardo Labá 